HARROD AND HIS TRADE CYCLE GROUP 
Also by Warren Young

INTERPRETING MR KEYNES: the $I S-L M$ Enigma 


\section{Harrod and his Trade Cycle Group}

The Origins and Development of the Growth Research Programme

Warren Young

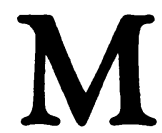

MACMILLAN 
(C) Warren Young 1989

Softcover reprint of the hardcover 1st edition 1989 978-0-333-47019-0

All rights reserved. No reproduction, copy or transmission of this publication may be made without written permission.

No paragraph of this publication may be reproduced, copied or transmitted save with written permission or in accordance with the provisions of the Copyright Act 1956 (as amended), or under the terms of any licence permitting limited copying issued by the Copyright Licensing Agency, 33-4 Alfred Place, London WC1E 7DP.

Any person who does any unauthorised act in relation to this publication may be liable to criminal prosecution and civil claims for damages.

First published 1989

Published by

THE MACMILLAN PRESS LTD

Houndmills, Basingstoke, Hampshire RG21 2XS

and London

Companies and representatives

throughout the world

British Library Cataloguing in Publication Data

Young, Warren, L.

Harrod and his Trade cycle group: the origins

and development of the growth research

programme.

1. Great Britain. Economic growth. Effects of trade cycles on research projects

I. Title II. Harrod, Roy (Roy Forbes), 1900-1978

III. Growth Research Programme in Economics

$338.9^{\prime} 0072041$

ISBN 978-1-349-10357-7

ISBN 978-1-349-10355-3 (eBook)

DOI 10.1007/978-1-349-10355-3 
For Professor James Meade and in memory of Sir Roy Harrod 


\section{Contents}

Acknowledgements viii

Preface xi

Introduction: Key Questions and Issues, Myths and Missing Links 1

Chapter 1: Harrod's Early Activities, 1924-34 15

Chapter 2: Individuals and Groups in Oxbridge, 1930-39 51

Chapter 3: Towards the Trade Cycle, 1934-35 74

Chapter 4: The Trade Cycle: Group, Critics and Critiques 97

Chapter 5: From the Trade Cycle to the 'Essay', 1935-39 148

Chapter 6: Overview and Conclusions - Harrod, Meade and the Growth Research Programme

$\begin{array}{ll}\text { Notes } & 202\end{array}$

Bibliography $\quad 214$

Index 222 


\section{Acknowledgements}

This book is dedicated to Sir Roy Harrod and Professor James Meade, whose fundamental contributions over 50 years ago changed the course of economic inquiry and brought about the growth research programme in economics. I want to thank Lady Harrod and Professor Meade for allowing me to cite from the Harrod-Meade correspondence in the Meade papers.

The Harrod papers are now held at Chiba University of Commerce, Ichikawa, Japan. They comprise, after the Keynes papers, perhaps the richest store of material for the history of economic thought this century. I wish to express here my deepest gratitude to Professor Y. Hayakawa, the President of Chiba University of Commerce, Y. Harada, the Chairman of the Board of Directors, Y. Tojo, the Director, General Affairs, and Professor R. Iwaki, Librarian of Chiba University of Commerce, for permission to cite at length from the Harrod papers, and also for their kind hospitality and assistance during my stay in Ichikawa.

In addition, my Japanese friends, Professors T. Nagashima and $\mathrm{K}$. Iwai of Tokyo University, Professor N. Masuda of Toyama University, and Professor K. Kakihara of Chiba University, were of great help during my all-too-brief stay in Japan.

I was only able to get to Ichikawa, however, due to the kindness and co-operation of my former colleagues at the Victoria University of Wellington, New Zealand, where I spent the academic year 1987 as a visiting senior lecturer in economics. Financial assistance for my research efforts was provided by the internal research fund, and the Economics group research fund, Victoria University of Wellington, and the economics research fund of the Reserve Bank of New Zealand. I am most grateful for their assistance, and I wish to thank in this regard Professor S.H. Franklin, Dr L. Evans, Dr G. Wells, and also Mr P. Nicholl, Deputy Governor of the Reserve Bank of New Zealand.

I also want to again thank Professor S. Dennison for providing me with material from the Robertson papers, and for his kind permission to cite at length from the letters of Professor Sir Dennis Robertson. I also want to thank Maurice Allen for permission to cite from his letters to Harrod, and Professor Liz Durbin, for both sending me copies of letters from the papers of her father, the late Evan Durbin, 
and permission to cite from them here.

I also want to thank Professor H. Hagemann and the Faculty of Economics, University of Bremen, for inviting me to present material contained in this book at their seminar in July 1988, and Professors L. Jonung and B. Hansson of the Department of Economics, University of Lund, for inviting me to the "Conference on the Stockholm School after 50 years', where material on Harrod and Lundberg was presented in August 1987.

The following individuals acted - sometimes even without knowing it - as 'intellectual sounding boards' for my sometimes incoherent ideas and interpretations, and I want to thank them for putting up with me: Professor Sir John Hicks, Professor Paul Samuelson, Professor Robert Clower, Professor William Baumol, Professor Don Patinkin, Professor Ralph Turvey, Professor Axel Leijonhufvuud, Professor Wynne Godley, Professor Frank Hahn, Professor Kenneth Arrow, Professor Hans Brems, and last but not least, Professor James Meade himself. Dr Charles Hitch also greatly assisted my efforts in understanding the crucial importance of Professor Meade's early work - both published and unpublished.

I also want to thank my former colleagues at the Victoria University of Wellington for actively assisting the development of my ideas on the subject of this book: Professor David Sheppard, Professor Bryan Philpott, Professor Barbu Niculescu, Dr Graeme Wells, Dr Geoff Bertram, Dr Lew Evans, Dr John Zanetti, Dr Mohammed Khaled, Dr Neil Quigley, Mr Bob Buckle, and Mr Bob Stephens. All put up with my constant 'Eureka!', until I really found the 'missing links'.

The impetus for this research emanated out of previous work I had done on Harrod, and long and fruitful conversations with Drs Geoff Harcourt and Peter Clarke of Cambridge University. I also want to thank in this context the Master of my college, Churchill, Professor Sir Hermann Bondi, and the college registrar, Miss M. Beveridge, for their kindness in arranging accommodation during my visits to the Faculty of Economics and Politics at Cambridge over $1985-8$.

The friendship and support of Dr David and Mrs Suzette Pearson, and $\mathrm{Mr}$ Don Stewart, enabled me to get through the watery Wellington, N.Z. spring after my family had returned to a warmer clime. The hospitality of Dr David and Mrs Margaret Toase in Cambridge, and Mr Sam and Mrs Miri Klibansky in London, also helped me through the long separation involved in trying to 
conduct research away from one's family. And it is thus my wife Sara and daughters Shani and Natalie who deserve the most thanks, for allowing me to spend so much time away from home, again, engaged in 'hagiography'. 


\section{Preface}

Sir Roy Harrod has been described as second only to Keynes amongst economists in terms of the originality of his contributions to modern economic thought. Even the renowned economist and Nobel Laureate, Sir John Hicks, noted his own long-standing intellectual debt to Harrod in his Nobel Lecture, when he acknowledged the fact that Harrod's work, in essence, provided him with many fertile ideas which he further developed in the course of his own distinguished career.

Harrod was instrumental in discovering and developing - both on his own and with the assistance of others, as in the case of Keynes some of the most fundamental and profound concepts in modern economics. These include the notion of the marginal revenue curve, the IS-LM approach to Keynes's General Theory, the dynamic extension of the Keynesian system, and he is universally recognised as the father of modern growth theory in economics.

In fact, if Keynes was considered by the economics profession to be the 'sorcerer', then Harrod was his very independent minded 'apprentice'. Indeed, Harrod tried to go further than Keynes by expanding his scope. However, while Harrod ventured into areas of economic theory that Keynes left untouched, he also continuously tried to integrate and reconcile Keynes's views with the 'mainstream' of economic thought. Thus, the relationship between Keynes and Harrod, and even more so, the relationship between Harrod and the Cambridge 'Keynesians', was never like that between Keynes and his Cambridge 'disciples', as Robertson called them. Although reproached and admonished by Keynes many times over their disagreements regarding Keynes's General Theory approach, Harrod never became discouraged. Rather, he remained adamant in his attempt to dynamise and thereby, in his view, generalise Keynes, and also to integrate Keynes's General Theory approach with mainstream theory as he understood and interpreted it.

Now, although Harrod's published work on the trade cycle, growth, and dynamics only appeared between 1934 and 1939, he actually began to think about these problems during the 1920s. After taking his degree at New College, Oxford, and having been elected a teaching fellow at Christchurch, he spent two terms, during 1922-3, working with and under the supervision of Keynes at Cambridge. 
Upon his return to Oxford, Harrod wrote a number of essays on the trade cycle, growth, and distribution over the period 1924-33, which, although never published, must be dealt with in the context of the evolution of his economic thought. This early work, along with the later input he received from what he called his Trade Cycle group and others - such as Robertson - during the mid-1930s, assisted him both in formulating his ideas as published in The Trade Cycle (1936a), and in the transition to his theory of growth and dynamics, as manifest in his 'Essay in Dynamic Theory' (1939a).

While much has been written about the issues emanating from Harrod's mainstream contributions in the field of economic growth and dynamics, with some work also recently appearing on other specific aspects of what can be called 'Harrodian economics' - and a systematic treatment of Harrod's economic world view and detailed survey of his many contributions to economic thought is long overdue - up to now, all analyses of Harrod's contributions have been based upon either published and secondary sources, or limited to the Keynes-Harrod correspondence as published in Keynes's collected writings. The material to be presented in this book, however, is based upon previously unpublished essays, manuscripts, and correspondence found in the Harrod and Meade papers, and therefore throws entirely new light on the origins and development of his ideas.

In the introduction to the book, the key questions and issues to be dealt with are presented, and the necessity for reassessment, reconstruction, and retrospective appraisal of the origins and development of Harrod's contribution outlined. In the first chapter, Harrod's unpublished early work on the trade cycle, growth, and distribution initially set off by Keynes's Tract, and subsequently influenced by the Treatise, as will be seen - are surveyed. These include an essay on the trade cycle and income distribution (1924), a memo on the effect of falling prices on employment (1926a), an essay on the trade cycle (1926b), and an essay on the political economy of the trade cycle (1933b). In this context, Harrod's published work - such as his book International Economics (1933a), and critiques of Robertson (1927) and Pigou (1934a) - is placed in the perspective of correspondence between Harrod and Robertson, and Harrod and Keynes respectively, and also in that of his evolving approach to the trade cycle and growth.

In the second chapter the intellectual background to the development of the growth research programme is set out by focusing on the interests of individuals and groups in Oxbridge over the period 
1930-39. While the activities of the 'Cambridge Circus' (1931), the subsequent 'General Theory group' (1934-6), and the Oxford Economists Research Group (OERG) have been documented, this chapter deals with the significance of the early and ongoing work of the members of what Harrod called his 'Trade Cycle group'. This is done by focusing on the degree of cross-fertilisation and exchange of ideas between Oxford-based economists such as Harrod, Meade, Allen, Fraser, and Hitch, and their Cambridge counterparts such as Robertson, Kahn, and Joan Robinson. In this context, almost totally forgotten volumes such as Meade's Rate of Interest in a Progressive State (1933), and various editions of his Economic Analysis and Policy (1936b; 1937; 1938; American version edited by Hitch), along with Fraser's Economic Thought and Language (1937) - in addition to critical evaluations of contemporary works on the trade cycle and economic methodology by Allen and Fraser, for example - are seen to provide a background for Harrod's ongoing interest in the problems of the trade cycle and growth.

In chapter 3, Harrod's progress in explaining the trade cycle and economic growth is dealt with by focusing on the years 1934-5, during which he was engaged in defending the position he took in his paper on credit expansion and economic advance published in Economica (1934d). Over this period he became involved in both public debate and private correspondence on the issues he raised in this paper with Robertson, Haberler, Bode, Kaldor, and Kahn. The first section of the chapter deals with the 1934 exchanges between Harrod and Robertson - both public and private. The second section presents the public debate and private correspondence between Harrod and Haberler, Bode, and Kaldor on his 1934 paper. The third section focuses on the correspondence between Harrod and Kahn on the issues that emerged from his 1934 paper. Finally, this chapter also deals with the 1934 League of Nations memorandum sent by Haberler to Harrod for comment, and which became the basis for Haberler's book Prosperity and Depression (1936). The previously unknown but important correspondence between Harrod and Haberler on this forms the final section of this chapter.

Chapter 4 focuses upon the central role of Harrod's book The Trade Cycle (1936a) in the evolution and development of his thought. The correspondence between Harrod and Robertson on the draft manuscript of the book over the period 1936-7, and Harrod and Henderson during 1936, is dealt with, as is the crucial influence of Meade, and also of Allen, on the book's development. In addition, 
this chapter deals with both the place of the 1936 Oxford Conference, and the role of what Harrod called his 'Trade Cycle group' in the development of his approach, and also shows the previously unknown early contribution of Meade (1936a) to Harrod's approach and to the growth research programme as a whole. Finally, the impact of the various critiques and reviews of the book upon Harrod - ranging from that of Keynes to those of Robertson, Hawtrey, Robinson, Tinbergen, Haberler, and Hansen, among others - is evaluated.

In chapter 5 the transition from Harrod's book on the trade cycle (1936a) to his 'Essay in Dynamic Theory' (1939a) is dealt with, focusing especially on a number of influences which may have assisted him in formalizing the analysis of growth and dynamics he actually presented, on his own account, in his 1936 work. This includes the impact of Cassel, Kalecki, Lundberg, Tinbergen, Lange, Hawtrey, Robertson, Robinson, and Durbin upon Harrod's thought; the correspondence on the draft of the 'Essay' between Harrod and Keynes, and the previously unknown exchange on it between Harrod and Robertson; and finally, the contribution of Marschak - described by Harrod at the time as the Oxford Institute of Statistics' 'Tinbergen' - to the development of Harrod's growth and dynamic theory. In this context, Marschak's previously unknown, but crucial detailed 'remarks' and diagram (1939), based upon the draft of Harrod's 1939 'Essay' - which was found in the Harrod papers - are presented and analysed.

In the final chapter conclusions regarding Harrod's approach are presented in the perspective of an overview of specific problems involved in its origins, development, central message, and core concepts. These include the issues of antecedents and precedence as they relate to Cassel, Lundberg, and Domar; the relationship between Harrod's work and that of Meade, Hicks, and Solow; the notions of warranted and optimum growth, systemic instability, 'Treatise Saving', and the 'knife-edge', and what Harrod's central message really was; and finally, the role Harrod's approach actually played in catalysing the Harrod-Meade growth research programme in economics. 